\title{
Perbanyakan Agen Hayati Trichoderma Sp. Menggunakan Media Beras di Laboratorium Pengamatan Hama dan Penyakit Tanaman Banyumas
}

\section{Propagation of Biological Agents of Trichoderma Sp. using Rice Media in Banyumas Pest and Disease Observation Laboratory}

\author{
Windi Haristia ${ }^{1}$, Ardiana Kartika B ${ }^{2}$, Teguh Pribadi ${ }^{3}$ \\ ${ }^{1,2,3}$ Program Studi Agroteknologi Fakultas Pertanian dan Perikanan \\ Universitas Muhammadiyah Purwokerto
}

\begin{tabular}{l}
\hline ARTICLE INFO \\
\hline Article history: \\
DOI: \\
10.30595/pspfs.v2i.192
\end{tabular}

Submitted:

July 29, 2021

Accepted:

Sept 10, 2021

Published:

Nov 10, 2021

\begin{abstract}
The rhizosphere area of a plant is an area rich in microbes, one of which is a group of fungi. This practical work aims to multiply Trichoderma sp. in the rhizosphere of bamboo plants in the Jatilawang area using rice as a medium. This practical work uses rice and coconut media in conducting exploration. The results of practical work obtained spore density of Trichoderma sp. meet the standards for application in plants. Obstacles in exploring Trichoderma sp. is takes a long time.
\end{abstract}

This work is licensed under a Creative Commons Attribution 4.0 International License.

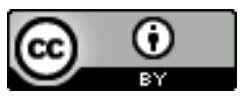

Keywords:

Rice, Propagation, Trichoderma

\author{
Corresponding Author: \\ Windi Haristia \\ Program Studi Agroteknologi Fakultas Pertanian dan Perikanan \\ Universitas Muhammadiyah Purwokerto \\ Email: windiht04@gmail.com
}

\section{PENDAHULUAN}

Latar Belakang

Dalam pencapaian produksi tanaman, fungsi perlindungan tanaman merupakan bagian penting dan tidak terpisahkan dalam menjaga kualitas, kuantitas dan kontinuitas hasil peroduksi. Undang-Undang No 12 tahun 1992 mengungkapkan bahwa pelaksanaan perlindungan tanaman diterapkan dengan sistem Pengendalian Hama Terpadu (PHT), dan dalam pelaksanaan pengendalian perlu mempertimbangkan aspek pencemaran dan kerusakan lingkungan serta menjaga kelestarian serangga dan mikroorganisme yang merupakan musuh alami. Trichorderma sp. adalah jamur yang memiliki daya adaptasi luas, paling banyak terdapat di dalam tanah. Di samping peranannya sebagai jamur antagonis, juga berfungsi sebagai organisme pengurai dan stimulator pertumbuhan tanaman (Chet, 1987).

Dalam memasuki pasar global, persyaratan produk-produk pertanian ramah lingkungan menjadi prioritas. Salah satu alternatif upaya peningkatan kuantitas dan kualitas produk pertanian dapat dilakukan dengan pemanfaatan agen hayati (biopestisida) sebagai pengganti pestisida sintetik, serta pemanfaatan agen hayati 
sebagai stimulator pertumbuhan tanaman dan pendegradasi unsur hara. Jamur Trichoderma sp banyak dijumpai hampir pada semua jenis tanah dan merupakan salah satu jenis jamur yang dapat dimanfaatkan sebagai agen hayati pengendali patogen dan stimulator pertumbuhan tanaman. Trichoderma banyak memiliki spesies. Spesies Trichoderma diantaranya adalah Trichoderma reesei, Trichoderma viride, dan Trichoderma harzianum (Schuster dan Schmoll, 2010).

Hasil penelitian Alfizar dkk (2013), Trichoderma sp dapat menghambat pertumbuhan cendawan patogen C. capsici, Fusarium sp, dan S. rolfsii secara in vitro. Trichoderma sp efektif menghambat pertumbuhan Sclerotinia sclerotiorum, Fusarium oxysprum, dan Altenaria brassicicola yang merupakan patogen tanaman (Manokaran, 2016). Penelitian Shofiyani dan Suyadi (2014), perlakuan agensis hayati Trichoderma dengan berbagai dosis berpengaruh nyata terhadap parametar jumlah daun dan jumlah umbi, pada kisaran dosis $40 \mathrm{~g} /$ lubang tanam memberikan pengaruh terbaik terhadap pertumbuhan tanaman bawang merah selama penelitian.

Serangan OPT dapat disebabkan oleh serangga maupun patogen. Dari berbagai penyakit tanaman tomat, penyakit layu fusarium merupakan penyakit yang dominan. Menurut Semangun (1996), patogen layu fusarium pada tanaman tomat adalah cendawan Fusarium oxysporum. Cendawan ini merupakan cendawan patogen tular tanah yang dapat menyerang tanaman tomat. Menurut Endah dan Novizan (2002), cendawan patogen tular tanah dapat dikendalikan dengan cara menanam varietas tomat yang tahan, penggunaan mulsa plastik, dan perlakuan benih. Cara ini belum memberikan hasil yang memuaskan. Teknik pengendalian yang paling banyak diterapkan adalah aplikasi fungisida sintetik. Tetapi, fungisida ini harganya cukup mahal, selain itu pemakaian fungisida secara terus-menerus dapat menimbulkan dampak negatif bagi lingkungan seperti resistensi patogen, pencemaran lingkungan, dan matinya organisme non target (Oka, 1995). Menurut Novizan (2002), teknik pengendalian lain dapat dilakukan dengan memanfaatkan agen hayati yang bersifat antagonis, salah satunya yaitu Trichoderma sp. Selain bersifat hiperparasit terhadap cendawan patogen tular tanah, cendawan antagonis ini juga bersifat dekomposer yang dapat mempercepat proses pembuatan kompos. Penambahan Trichoderma $\mathrm{sp}$ dan fermentor biomassnya seberat $200 \mathrm{~g}$ dan $250 \mathrm{~g} / 5 \mathrm{~kg}$ tanah media semai sangat mampu menekan pertumbuhan dan perkembangan jamur S. rollfsii patogen rebah kecambah pada tanaman cabai di persemaian (Mulyati dkk., 2002). Penelitian ini bertujuan untuk mengetahui peran Trichoderma sp dalam pengendalian penyakit layu fusarium pada tanaman tomat.

Potensi Trichoderma sebagai agens pengendali hayati sudah tidak terbantahkan. Beberapa penyakit sudah dapat dikendalikan dengan aplikasi Trichoderma, antara lain Sclerotium rolfsii, Fusarium oxysporium, dan Rhizoctonia solani (Kalay, 2005) Phytophthora infestans (Purwantisari et al., 2008), Phytophthora drechsleri (Tehrani dan Nazari, 2004). Di samping karakternya sebagai antagonis, Trichoderma juga berfungsi sebagai dekomposer dalam pembuatan pupuk organik. Trichoderma juga mempunyai kemampuan untuk meningkatkan kecepatan pertumbuhan dan perkembangan tanaman, terutama kemampuannya untuk menyehatkan pertumbuhan akar dan meningkatkan angka kedalaman akar di bawah permukaan tanah. Akar yang lebih dalam menyebabkan tanaman menjadi lebih resisten terhadap kekeringan, seperti pada tanaman jagung dan tanaman hias (Harman, 1991). Aplikasi Trichoderma pada pembibitan tanaman juga dilakukan untuk mengantisipasi serangan organisme pengganggu tanaman (OPT). Hal ini membuktikan bahwa tingkat kesadaran petani akan arti penting perlindungan preventif telah dilakukan. Penggunaan Trichoderma secara luas dalam usaha pengendalian OPT perlu disebarluaskan agar petani-petani Indonesia dapat memproduksi Trichoderma secara mandiri (Kalay dan Talahaturuson, 2014).

Metode pengendalian yang sering dilakukan oleh para petani yaitu penggunaan bahan pestisida sintetik yang melebihi dosis anjuran dan digunakan secara terus-menerus sehingga mengakibatkan akumulasi pestisida di tanah. Akumulasi pestisida yang tinggi menimbulkan dampak negatif terhadap lingkungan bahkan ke tingkat konsumen. Untuk itu, alternatif pengendalian yang ditawarkan adalah penggunaan agens hayati seperti Trichoderma sp. (Taufik, 2008).

Salah satu alternatif pengendalian yang memberikan harapan untuk dikembangkan yaitu pengendalian hayati dengan menggunakan jamur antagonis Trichoderma spp. Mekanisme Trichoderma spp. dalam mengendalikan berbagai jenis patogen tanaman dapat dibedakan secara langsung dan tidak langsung terhadap patogen. Menurut Harman (2000), mekanisme secara langsung berupa kompetisi, hiperparasit, antibiosis dan lisis. Harman dkk. (2004) melaporkan bahwa mekanisme tidak langsung terhadap patogen diantaranya memperkuat sistem perakaran, meningkatkan pertumbuhan tanaman, meningkatkan ketersediaan hara dan menginduksi ketahanan tanaman.

\section{Perumusan Masalah}

Berdasarkan latar belakang diatas, dapat dirumuskan masalah sebagai berikut:

1. Bagaimana cara perbanyakan Tricodherma sp. pada media beras?

2. Bagaimana kendala perbanyakan Tricodherma sp pada media beras dan cara mengatasinya?

\section{Tujuan}

Tujuan dari penelitian ini adalah: 
1. Menguraikan proses perbanyakan Tricodherma sp. dengan media beras.

2. Menguraikan kendala perbanyakan Tricodherma sp. dengan media beras dan cara mengatasinya.

\section{METODE PENELITIAN}

Bahan

Bahan yang dipakai adalah jamur Tricodherma sp, beras, alkohol, air, agar, sukrosa, dan kelapa.

Alat

Peralatan yang dipakai adalah kompor, dandang pengukus, jarum ose, kotak incase, bunsen, kapas, autoklaf, presto, tabung reaksi, gelas beker, timbangan, cawan petri, mikroskop, haemocytometer, pipet ukur, pipet tetes, rak tabung reaksi, bambu, dan hand counter.

Tahap Pelaksanaan

Tahapan pelaksanaan kegiatan penelitian terdiri dari 3 tahap, yaitu tahap persiapan, tahap pelaksanaan dan tahap penyelesaian.

Tahap Persiapan

Kegiatan yang dilakukan adalah menyelesaikan seluruh keperluan administrasi dan melengkapi syaratsyarat penelitian, pengumpulan referensi atau studi pustaka yang berhubungan dengan masalah yang dikaji serta penyusunan proposal penelitian.

Tahap Pelaksanaan

Kegiatan yang dilakukan pada tahap ini yaitu melakukan eksplorasi Trichoderma sp dengan dua media yakni dengan kelapa dan nasi, selanjutnya membuat media Potato Sukrose Agar (PSA) untuk perbanyakan jamur Trichoderma sp, selanjutnya menginokulasi Trichoderma sp pada media PSA. Setelah itu dilakukan pembuatan media beras siap aplikasi, kemudian menginokulasi Trichoderma sp pada media beras siap aplikasi, terakhir yaitu menghitung kerapan spora Trichoderma sp pada media beras siap aplikasi.

Tahap Penyelesaian kegiatan.

Kegiatan yang dilakukan pada tahap penyelesaian yaitu pengumpulan data dan pengumpulan laporan

\section{HASIL DAN PEMBAHASAN}

Eksplorasi Trichoderma sp. Langkah awal dalam perbanyakan agen hayati ini yaitu terlebih dahulu dilakukan ekplorasi atau pencarian sumber dari agen hayati ini. Sumber dari Trichoderma sp dapat diperoleh salah satunya dari rizosfer bambu. Indigenous knowledge yang dimiliki oleh petani yaitu belajar dari alam. Bambu merupakan tanaman yang hampir tidak pernah terserang oleh penyakit. Analisis alami yang dimiliki petani menyimpulkan tanah di sekitar bambu baik untuk pertumbuhan tanaman lain. Petani sangat sering menggunakan tanah humus dan tanah di sekitar perakaran bambu sebagai media untuk penyemaian benih tanaman. Sampai saat ini banyak laporan yang mengatakan bahwa tanah asal rizosfer bambu banyak tumbuh jamur dan bakteri antagonis yang dapat menekan pertumbuhan pathogen (Susanti, 2015). Pada tahap eksplorasi ini dilakukan sebanyak dua kali dengan menggunakan media eksplorasi yang berbeda-beda yaitu eksplorasi pertama menggunakan media kelapa sedangkan eksplorasi kedua menggunakan media nasi.

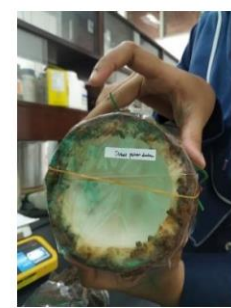

(a)

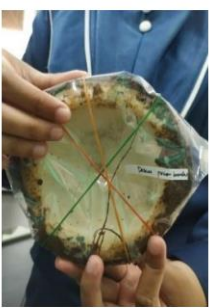

(b)

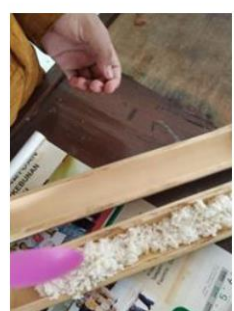

(c)

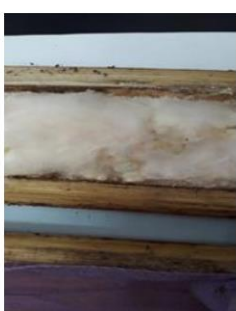

(d)

Gambar 1. Eksplorasi menggunakan media kelapa dan nasi (a) Kelapa H+3 dekat pohon durian, (b) Kelapa $\mathrm{H}+3$ dekat pohon bambu, (c) eksplorasi lanjutan dengan nasi dalam bambu, (d) media nasi pada $\mathrm{H}+3$.

Eksplorasi pertama menggunakan kelapa tua karena kelapa berwarna putih sehingga akan memudahkan dalam mengamati jamur yang tumbuh. Menurut Subagio (2011) daging buah kelapa yang sudah tua mengandung kalori yang tinggi, sebesar 354 kal per 100 gram, yang berasal dari minyak kurang lebih 33\%, karbohidrat $15 \%$ dan protein $3 \%$, selain itu juga memiliki kadar air sehingga sangat mendukung untuk pertumbuhan jamur. Untuk melakukan eksplorasi terlebih dahulu kelapa dibelah menjadi 2 bagian, kemudian masing-masing keping kelapa ditanam pada 2 tempat yang berbeda, yaitu di dekat pohon durian dan di dekat pohon bambu. Setelah 3 hari kelapa yang di tanam diambil dan diamati. Berdasarkan hasil pengamatan terdapat jamur berwarna hijau, kemudian jamur hijau tersebut diinokulasi pada cawan petri berisi Potato Sukrose Agar (PSA). Kemudian 4 hari setelah inokulasi (HSI), dilakukan pengamatan jamur dengan mikroskop. Pada hasil 
eksplorasi dengan kelapa tidak ditemukan jamur Trichoderma sp. Jamur berwarna hijau yang tumbuh pada kelapa tersebut bukan Trichoderma sp. karena memiliki morfologi yang berbeda, seharusnya berdasarkan gambar pada buku Barnet dan Hunter (1998) spora Trichoderma sp. berbentuk bulat kecil dan memiliki miselium yang bercabang 3 namun pada hasil ekplorasi spora yang ditemukan berbentuk lonjong dan besar serta memiliki miselium dengan cabang yang tidak beraturan.

Eksplorasi lanjutan atau eksplorasi kedua ini menggunakan media nasi. Nasi dipilih karena berwarna putih sehingga akan memudahkan saat pengamatan jamur yang tumbuh, selain itu juga nasi mengandung karbohidrat dan air yang dapat mendukung pertumbuhan jamur. Eksplorasi Trichoderma sp. diawali dengan memasukkan nasi ke dalam bambu yang sebelumnya sudah dibelah secara vertikal, kemudian bambu diikat dengan menggunakan tali, ikatan tidak boleh terlalu rapat sehingga masih ada celah untuk masuknya udara maupun jamur. Kemudian bambu yang sudah diisi dengan nasi tersebut dikubur di dalam tanah di dekat perakaran bambu. Setelah 3 hari dilakukan pengamatan, namun pada nasi tersebut jamur yang tumbuh tidak ada yang berwarna hijau seperti jamur Trichoderma sp., sehingga tidak dilakukan pengamatan menggunakan mikroskop.

Penyebab kegagalan eksplorasi Trichoderma sp. menggunakan media nasi dan media kelapa disebabkan oleh kedalaman media eksplorasi tidak cukup yakni hanya di bagian permukaan tanah, sedangkan seharusnya menurut Syahputra dkk (2017) dibenamkan pada kedalaman $15 \mathrm{~cm}$. Selain itu, media eksplorasi ditanam agak berjauhan dari pangkal tanaman bambu sehingga tidak terlalu dekat dengan akar. Kegagalan juga bisa disebabkan oleh media yang tidak steril sehingga dimungkinkan terjadi kontaminasi oleh mikroba lain sehingga Trichoderma tidak dapat tumbuh.

Kendala dalam eksplorasi Trichoderma sp. yaitu membutuhkan waktu yang lama, serta dibutuhkan pengetahuan tentang ciri rizosfer yang memiliki kandungan Trichoderma sp. Ciri rizosfer (perakaran) bambu yang banyak mengandung Trichoderma sp. adalah tanaman sehat dan tidak terserang penyakit selain itu juga memiliki tanah yang gembur. Rata-rata pada akar bambu memiliki Trichoderma sp. karena bambu merupakan tanaman yang hampir tidak memiliki penyakit sehingga dimungkinkan banyak Trichoderma sp. ataupun agen hayati lain di dalam akar bambu tersebut (Susanti, 2015).

Dikarenakan ekplorasi Trichoderma sp. yang dilakukan gagal, untuk perbanyakan dan untuk melihat morfologi jamur Trichoderma sp. menggunakan koleksi hasil eksplorasi yang sudah ada di LPHP Banyumas.

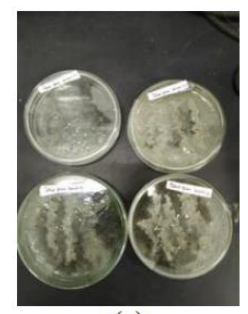

(a)

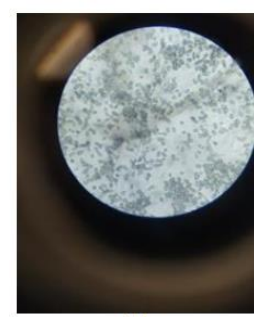

(b)

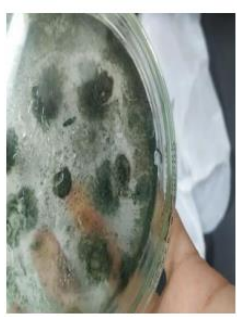

(c)

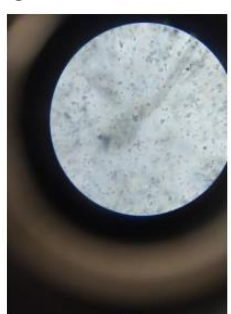

(d)

Gambar 2. Kenampakan Trichoderma sp. hasil eksplorasi. (a) 4 (empat) hari setelah inokulasi jamur pada kelapa, (b) kenampakaan Trichoderma sp. hasil eksplorasi dengan media kelapa pada mikroskop, (c)

Trichoderma sp. hasil eksplorasi koleksi LPHP Banyumas, (d) kenampakaan Trichoderma sp. hasil eksplorasi milik LPHP pada mikroskop.

\section{Inokulasi Trichoderma sp. pada media Potato Sukrose Agar (PSA)}

Inokulasi Trichoderma sp. pada PSA dilakukan bertujuan untuk memperbanyak isolat Trichoderma sp. hasil ekplorasi, selain itu hasil perbanyakannya nantinya akan digunakan untuk menginokulasi pada media beras siap aplikasi. Sebelum menginokulasi Trichoderma sp. terlebih dahulu dilakukan pembuatan PSA. Pembuatan PSA ini dilakukan sesuai protokol di LPHP. Seperti namanya media ini terbuat dari campuran air rebusan kentang (potato), gula (sukrose), serta agar.

Cara pembuatan media PSA dilakukan dengan langkah sebagai berikut: langkah pertama yaitu menimbang 100 gr kentang, selanjutnya kupas kulit kentang tersebut dan potong kentang berbentuk dadu, kemudian kentang dicuci hingga bersih, lalu direbus pada $500 \mathrm{ml}$ air. Setelah mendidih, pisahkan kentang dan air dengan menggunakan saringan. Kemudian masukkan gula ke dalam air, lalu aduk sampai homogen kemudian saring larutan tersebut. Setelah itu, Panaskan kembali larutan, serta tambahkan agar sedikit demi sedikit serta sambil diaduk, jika sudah tidak ada gumpalan agar, masukkan larutan media tersebut ke dalam gelas beker sambil dilakukan penyaringan. Sebelum media mengeras, masukkan larutan media tersebut ke dalam tabung reaksi kemudian tutup mulut tabung dengan menggunakan kapas. Media yang dimasukkan ke dalam tabung reaksi kira-kira hanya $1 / 8$ dari volume tabung reaksi tersebut, tujuannya yaitu, agar nantinya saat tabung dimiringkan media tidak mengenai kapas yang dapat menyebabkan kontaminasi. Penutupan juga harus dilakukan dengan baik dan rapat sehingga saat dilakukan sterilisasi media dengan menggunakan autoklaf tutup 
tabung tidak terbuka. Setelah itu setiap 7 tabung reaksi digabungkan dengan kertas dan karet yang bertujuan untuk memudahkan penyusunan tabung reaksi untuk sterilisasi media dalam autoklaf (lihat gambar 3).

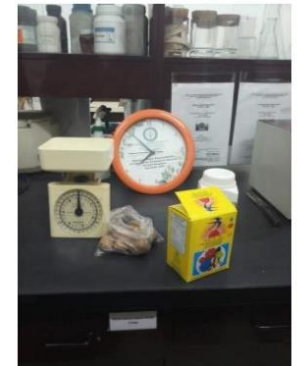

(a)

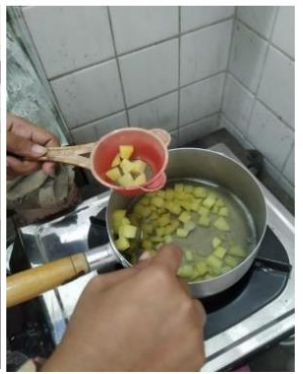

(b)

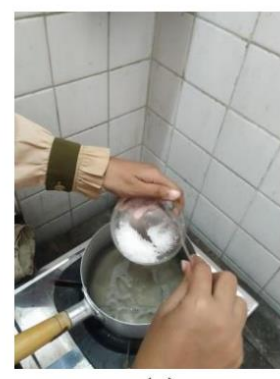

(c)

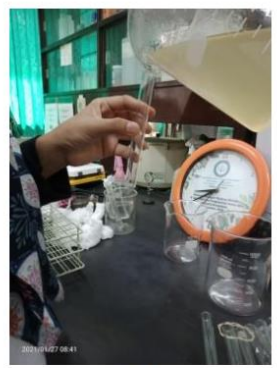

(d)

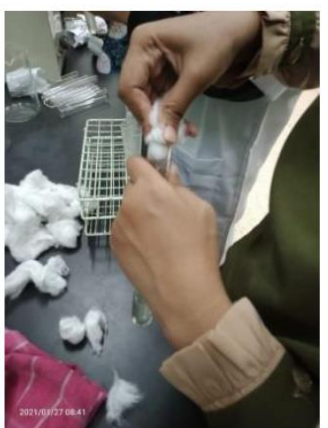

(e)

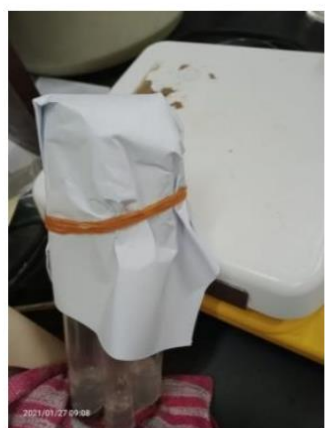

(f)

Gambar 3. Proses pembuatan media PSA. (a) mempersiapkan alat dan bahan, (b) merebus dan meniriskan kentang, (c) memasukkan sukrosa, (d) menuang larutan psa pada tabung reaksi, (e) menutup tabung dengan kapas, (f) menyatukan 7 tabung reaksi dengan kertas dan karet

Kemudian dilakukan sterilisasi media menggunakan autoklaf. Sterilisasi media diawali dengan mengisi air pada autoklaf, kemudian masukkan tabung reaksi, setelah itu tutup autoklaf dan kencangkan skrup penutupnya. Sambungkan autoklaf dengan listrik lalu buka katup autoklaf. Tunggu sampai katup mengeluarkan uap, lalu tutup katup tersebut. Setelah itu tunggu sampai pengukur tekanan berada di zona hijau. Apabila sudah berada di zona hijau, buka katup autoklaf, lalu matikan autoklaf tersebut. Setelah itu buka tutup autoklaf dan keluarkan tabung reaksi lalu susun dengan posisi miring. Hal ini bertujuan untuk memperluas permukaan media PSA dalam tabung reaksi. Kemudian biarkan media PSA dalam suhu ruang selama 2 hari sebelum dilakukan inokulasi Trichoderma sp.

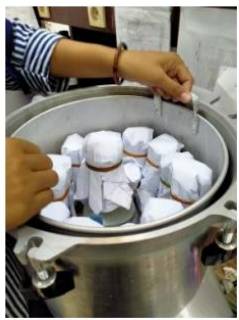

(a)

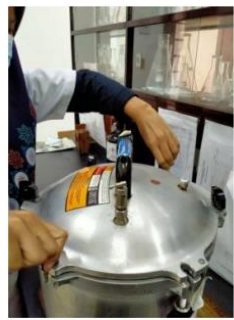

(b)

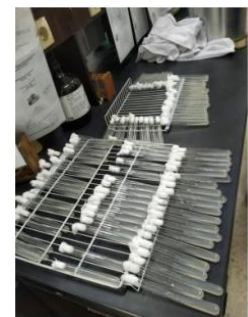

(c)

Gambar 4. Proses sterilisasi media PSA. (a) memasukkan media psa ke dalam autoklaf, (b) mengencangkan skrup penutup autoklaf, (c) menyusun tabung reaksi dengan posisi miring

Inokulasi Trichoderma sp. pada media PSA dilakukan di dalam kotak incase, kotak incase sebelumnya harus disterilkan menggunakan alkohol lalu digosok dengan menggunakan kapas. Setelah itu nyalakan bunsen di dalam kotak incase. Semprot tabung reaksi berisi media PSA dengan alkohol lalu masukkan ke dalam kotak incase, setelah itu sterilkan jarum ose dengan membakar pada bunsen sampai memijar, lalu ambil Trichoderma sp. hasil eksplorasi dengan hati-hati, lalu inokulasikan pada tabung reaksi berisi media PSA secara zig-zag. Perlu diingat bahwa, saat mengambil isolat Trichoderma sp. hasil eksplorasi pastikan jarum ose tidak terlalu panas, sehingga tidak membunuh jamur Trichoderma sp. tersebut. Kemudian biarkan media PSA yang sudah diinokulasi tersebut pada suhu ruang, serta amati pertumbuhan jamur Trichoderma sp. pada media tersebut. 
Berdasarkan hasil pengamatan terhadap pertumbuhan jamur Trichoderma sp. pada 11 tabung reaksi berisi media PSA, pada 1 Hari Setelah Inokulasi (HSI) sudah terlihat pertumbuhan hifa jamur berwarna putih kehijauan yang tumbuh pada goresan berbentuk zig zag hasil inokulasi, kemudian sampai pada 2 HSI sudah terlihat warna hijau dengan jelas pada beberapa tabung reaksi, perbedaan pertumbuhan pada masing-masing tabung bisa disebabkan karena perbedaan banyak jamur Trichoderma sp. pada saat inokulasi. Selanjutnya yaitu pada 3 HSI tidak terlihat lagi garis zig-zag hasil inokulasi karena seluruh permukaan media sudah terpenuhi oleh jamur Trichoderma sp. Kemudian pada 4 HSI, dari 11 tabung yang diamati terdapat 1 tabung dengan jumlah jamur Trichoderma sp. masih sangat sedikit, jamur Trichoderma sp. hanya tumbuh sedikit pada goresan hasil inokulasi, hal ini bisa disebabkan karena saat melakukan inokulasi jarum ose yang digunakan untuk mengambil isolat Trichoderma sp. masih sangat panas sehingga membunuh sebagian besar jamur Trichoderma sp. pada jarum ose tersebut. Pada 5 HSI dan seterusnya, Trichoderma sp. dimasukkan ke dalam kulkas untuk menjaga agar pertumbuhannya tidak terus berlangsung sehingga dapat disimpan dengan jangka waktu yang lama serta nantinya juga dapat dijadikan koleksi dan menjadi sumber untuk perbanyakan pada media beras siap aplikasi.

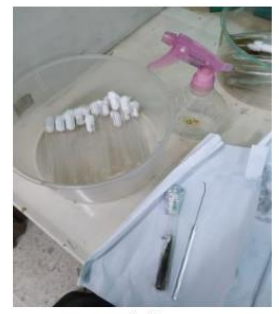

(a)

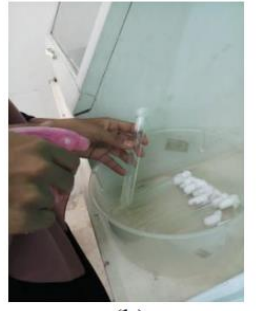

(b)

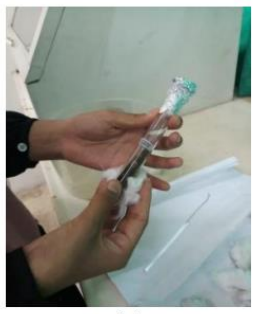

(c)

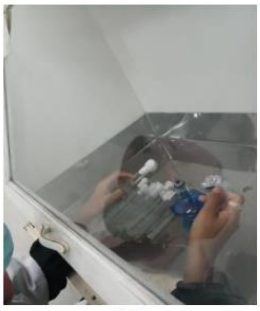

(d)

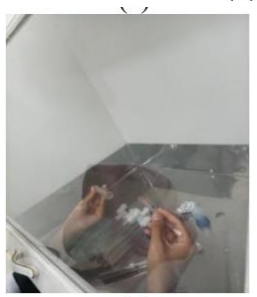

(e)

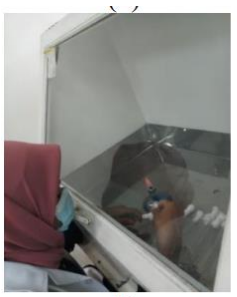

(f)

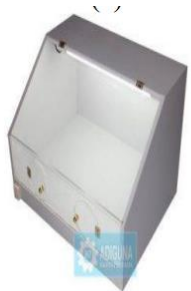

(g)

Gambar 5. Inokulasi Trichoderma sp. pada media PSA. (a) menyiapkan alat dan bahan, (b) mensterilkan tabung reaksi berisi media PSA, (c) mensterilkan isolat Trichoderma sp. hasil eksplorasi, (d) mensterilkan jarum ose menggunakan bunsen, (e) menginokulasi Trichoderma sp. ke dalam media PSA, (f) menutup tabung reaksi, (g) gambar kotak incase

Penyebab keberhasilan proses inokulasi Trichoderma sp. pada media PSA adalah kesterilan alat-alat seperti jarum ose dan kotak incase yang digunakan. Selain itu, inokulasi juga dilakukan berdekatan dengan bunsen dan setelah inokulasi tabung reaksi ditutup rapat menggunakan kapas. Kendala dalam melakukan inokulasi Tichoderma sp. pada media PSA adalah harus dilakukan dengan hati-hati dan sedikit sulit karena harus dilakukan didalam kotaak incase. Selain itu, karena inokulasi dilakukan berdekatan dengan bunsen, jika tidak hati-hati dapat menyebabkan kebakaran pada kapas penutup tabung reaksi.

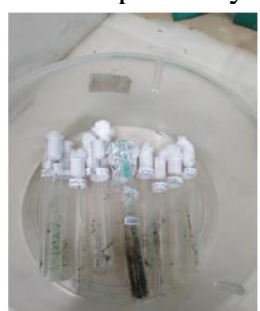

(a)

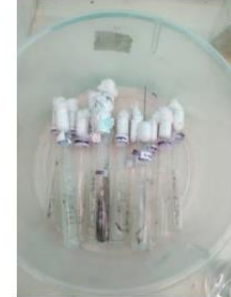

(b)

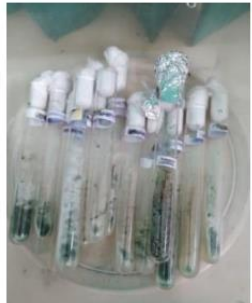

(c)

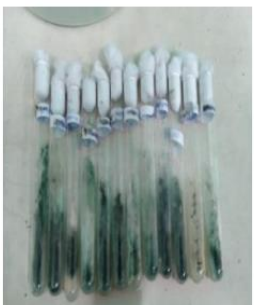

(d)

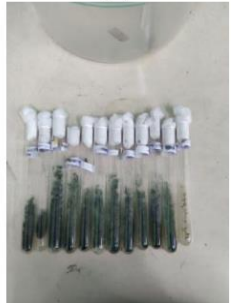

(e)

Gambar 6. Pertumbuhan jamur Trichoderma sp. pada media PSA. (a) 0 HSI, (b) 1 HSI, (c) 2 HSI, (d) 3 HSI, (e) 4 HIS

\section{Inokulasi Trichoderma sp. pada media beras siap aplikasi}

Sebelum menginokulasi Trichoderma sp. Pada media beras, dilakukan pembuatan media beras siap aplikasi yang diawali dengan menimbang $1 \mathrm{~kg}$ beras, kemudian mencuci beras hingga bersih, yakni hingga air cucian beras menjadi bening, setelah itu tiriskan. Masukkan air ke dalam dandang pengukus, tunggu sampai mendidih, lalu masukkan beras, kukus selama 15 menit. Setelah itu dinginkan beras, lalu masukkan 100 gr beras ke dalam plastik, kemudian sterilkan beras menggunakan presto selama 40 menit. Media beras siap aplikasi 
pada perbanyakan Trichoderma sp. kali ini disterilkan dengan menggunakan presto (tidak menggunakan autoklaf) karena terjadi kerusakan autoklaf di LPHP Banyumas. Kendala pada penggunaan presto adalah suhu yang digunakan tidak dapat ditentukan dengan pasti karena pemanasan pada presto menggunakan api sedang pada kompor gas (sekitar $130{ }^{\circ} \mathrm{C}$ ). Media beras yang sudah disterilkan, dibiarkan selama 1 hari pada suhu ruang sebelum dilakukan inokulasi Trichoderma sp.

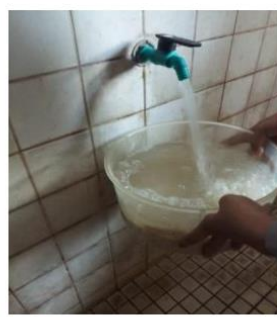

(a)

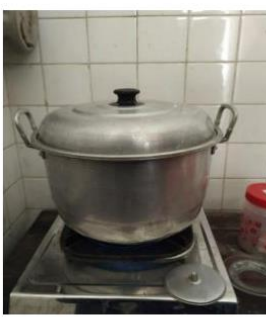

(b)

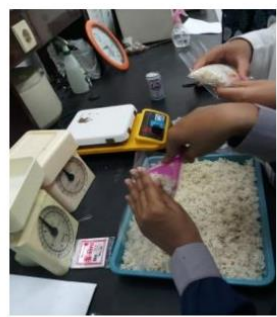

(c)

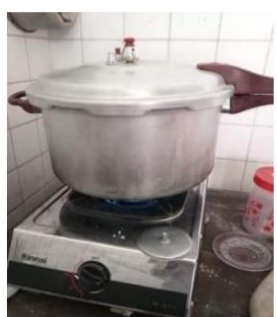

(d)

Gambar 7. Proses pembuatan media beras siap aplikasi. (a) mencuci beras, (b) mengukus beras selama 15 menit,

(c) memasukkan 100 gr beras ke dalam plastik, (d) sterilisasi media beras dengan presto selama 40 menit

Inokulasi Trichoderma sp. pada media beras siap aplikasi dilakukan di dalam kotak incase. Kotak incase sebelumnya harus disterilkan menggunakan alkohol, dengan menyemprotkan alkohol pada seluruh bagian kotak incase, lalu gosok menggunakan kapas. Kemudian nyalakan bunsen di dalam kotak incase, selanjutnya sterilkan jarum ose dan media beras menggunakan alkohol saat akan dimasukkan ke dalam kotak incase. Saat akan menginokulasi, sterilkan jarum ose dengan membakar jarum ose tersebut pada bunsen sampai memijar, kemudian buka penutup isolat Trichoderma sp. pada tabung reaksi, ambil menggunakan jarum ose, perlu diingat saat mengambil Trichoderma sp. menggunakan jarum ose diusahakan agar jarum dalam keadaan sudah tidak terlalu panas, sehingga tidak membunuh jamur Trichoderma sp. tersebut. Setelah itu masukkan jarum pada media beras. Rapatkan plastik dengan menggunakan straples, kemudian media beras diguncang-guncang untuk menyebarkan jamur Trichoderma sp. yang baru diinokulasi. Beri label dengan keterangan tanggal pada plastik, kemudian biarkan pada suhu ruang, dan amati pertumbuhannya.

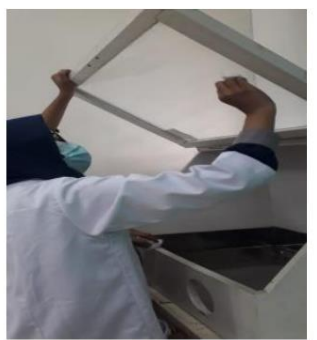

(a)

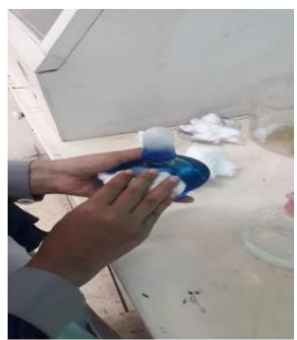

(b)

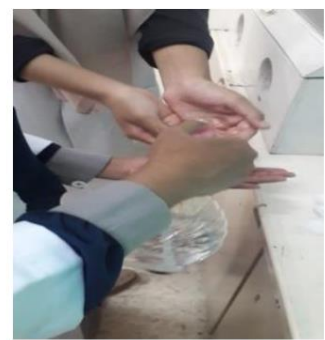

(c)

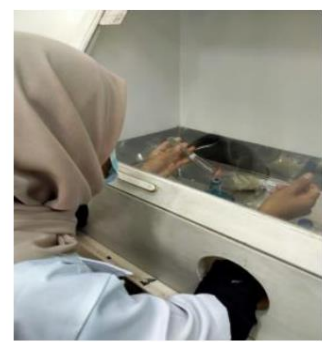

(d)

Gambar 8. Proses sterilisasi Trichoderma sp. pada media beras siap aplikasi. (a) membersihkan kotak incase, (b) mensterilkan bunsen, (c) mensterilkan tangan, (d) inokulasi dari media psa ke media beras

Setelah inolukasi, dilakukan pengamatan terhadap pertumbuhan jamur Trichoderma sp. pada media beras siap aplikasi. Pada 1 - 4 HSI belum terjadi pertumbuhan Trichoderma sp. Pada 5 HSI sudah terdapat bebrapa kantong media beras yang sudah ditumbuhi oleh Trichoderma sp. Selanjutnya pada 6 HSI dari 9 kantong media beras siap aplikasi terdapat 8 kantong yang sudah ditumbuhi Trichoderma sp. dan penyebaran jamur Trichoderma sp. sudah merata hampir ke seluruh media beras. Pada 7 HSI tidak terjadi perubahan yang terlalu signifikan, 1 kantong tetap berwarna putih, hal ini bisa disebabkan karena saat mengambil Trichoderma sp. pada media PSA jarum yang digunakan terlalu panas, sehingga membunuh Trichoderma sp. tersebut. Kemudian simpan media beras siap aplikasi di dalam kulkas. Media beras siap aplikasi dapat bertahan hingga 3 bulan jika disimpan dalam kulkas. Nantinya media beras siap aplikasi ini dapat digunakan untuk mengendalikan penyakit misalnya layu fusarium.

Faktor yang mempengaruhi pertumbuhan spora pada media beras yaitu suhu pertumbuhan yang optimal yakni $25-30{ }^{0} \mathrm{C}$. Selain itu juga dipengaruhi oleh media beras yang tidak terlalu keras, sehingga memudahkan bagi Trichoderma sp. untuk menyerap nutrisi. Kendala dalam inokulasi Trichoderma sp. pada media beras yaitu saat memasak beras tidak boleh terlalu matang, karena akan menyebabkan kandungan air pada media beras terlalu tinggi sehingga menyebabkan media beras terlalu lembab dan meransang pertumbuhan jamur lain serta dapat menyebabkan media memiliki umur simpan yang singkat. 


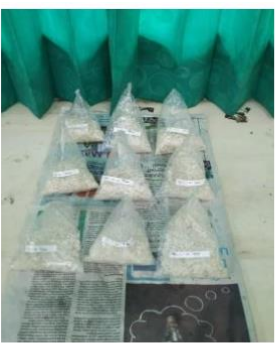

(a)

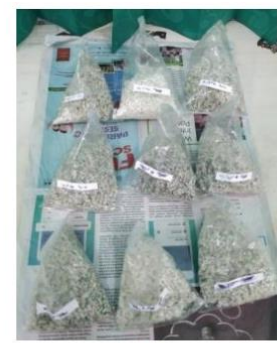

(b)

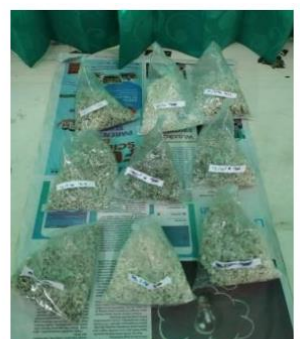

(c)

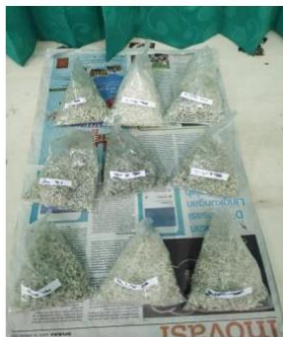

(d)

Gambar 9. Pertumbuhan jamur Trichoderma sp. pada media beras siap aplikasi.

(a) 0 HSI, (b) 5 HSI, (c) 6 HSI, (d) 7 HIS

\section{Perhitungan kerapatan spora Trichoderma sp. pada media beras siap aplikasi}

Perhitungan kerapatan spora pada media beras siap aplikasi ini dilakukan untuk mengetahui apakah media tersebut sudah memenuhi syarat kelayakan untuk dapat diaplikasikan pada tanaman. Untuk menghitung kerapatan spora, sebelumnya harus dilakukan pengenceran, hal ini bertujuan agar kepadatan dari spora dapat diminimalisir sehingga memudahkan dalam perhitungan spora Trichoderma sp. pada haemocytometer. Pengenceran diawali dengan membuat larutan induk, yaitu memasukkan 100 gr media beras siap aplikasi yang sudah ditumbuhi oleh Trichoderma sp. pada $500 \mathrm{ml}$ air, kemudian aduk sampai homogen. Stelah itu masukkan $10 \mathrm{ml}$ larutan induk pada tabung reaksi, dan siapkan 4 tabung reaksi berisi $9 \mathrm{ml}$ air serta beri label $10^{-1}, 10^{-2}, 10^{-}$ ${ }^{3}$, dan $10^{-4}$. Kemudian ambil $1 \mathrm{ml}$ larutan induk masukkan ke dalam tabung reaksi $10^{-1}$, setelah itu homogenkan. Kemudian ambil $1 \mathrm{ml}$ dari tabung $10^{-1}$ masukkan ke tabung $10^{-2}$, lalu homogenkan. Kemudian ambil $1 \mathrm{ml}$ dari tabung $10^{-2}$ masukkan ke tabung $10^{-3}$, lalu homogenkan. Terakhir ambil $1 \mathrm{ml}$ dari tabung $10^{-3}$ masukkan ke tabung $10^{-4}$, lalu homogenkan. Setelah dilakukan pengenceran amati kerapatan spora pada tiap tabung dari tabung $10^{-1}$ sampai $10^{-4}$ menggunakan haemocytometer dan diamati menggunakan mikroskop dengan perbesaran 100x. Ambil larutan pada tabung dengan menggunakan pipet tetes, kemudian teteskan pada haemocytometer. Amati dan hitung spora pada haemocytometer dengan hand counter.

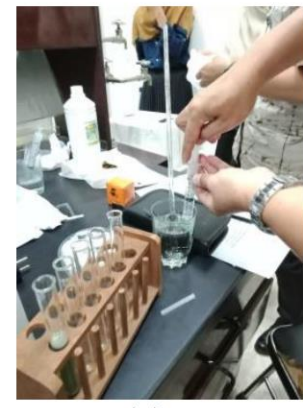

(a)

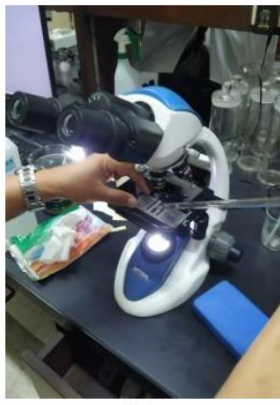

(b)

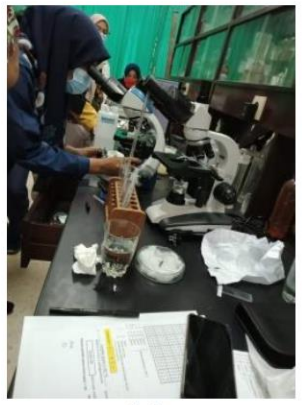

(c)

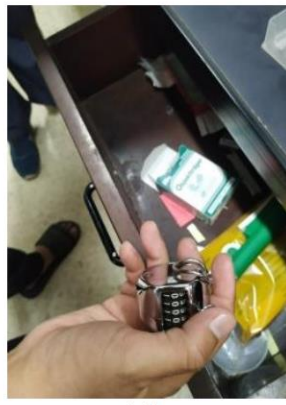

(d)

Gambar 10. Proses perhitungan kerapatan spora Trichoderma sp. pada media beras siap aplikasi. (a) melakukan pengenceran, (b) meneteskan larutan pada hemocytometer, (c) melihat dengan mikroskop, (d) menghitung dengan hand counter

Menurut LPHP Banyumas, spora yang dihitung pada haemocytometer yaitu spora pada kotak pertama di baris pertama (kotak paling kiri atas), kotak kedua di baris kedua, kotak ketiga di baris ketiga, kotak keempat di baris keempat, dan kotak kelima di baris kelima (kotak paling kanan bawah). Berdasarkan hasil perhitungan kerapatan spora didapatkan hasil yaitu pada tabung 10-1 kerapatannya 4,8 x $10^{6}$ spora per ml larutan, tabung $10^{-}$ ${ }^{2}$ kerapatannya $1,25 \times 10^{6}$ spora per ml larutan, tabung $10^{-3}$ kerapatannya $9 \times 10^{5}$ spora per ml larutan, dan tabung $10^{-4}$ kerapatannya $2 \times 10^{5}$ spora per ml larutan.

Pusat Penelitian dan Pengembangan Perkebunan (2014), menyatakan bahwa kerapatan spora yang sesuai standar untuk agens biokontrol atau agens pengendali hayati Trichoderma sp yaitu harus memiliki nilai lebih besar atau sama dengan 1 x $10^{6} \mathrm{spora} / \mathrm{ml}$. Dengan demikian dari kerapatan spora yang diperoleh menunjukkan bahwa jumlah spora yang dihasilkan oleh Trichoderma sp. dalam uji ini memenuhi persyaratan mutu agens pengendali hayati. Syahnen dkk., (2014), menyatakan bahwa kerapatan spora yang tinggi atau memenuhi standar akan menjadi indikator kemampuan agens pengendali hayati dalam menekan infeksi patogen.

Faktor yang mempengaruhi jumlah kerapatan spora Trichoderma sp. pada media beras yaitu umur Trichoderma sp. setelah inokulasi. Trichoderma sp. tumbuh optimal pada media beras di hari ke-7. Sehingga 
setelah hari ke-7 untuk memperpanjang umur simpan media beras yang berisi Trichoderma sp. harus disimpan pada lemari pendingin untuk menghentikan aktivitasnya.

Hal yang harus diperhatikan saat perhitungan kerapatan spora Trichoderma sp. pada media beras adalah dibutuhkan kemampuan dalam memakai mikroskop dan haemocytometer. Saat melakukan perhitungan dibutuhkan ketelitian karena harus melihat dan menghitung spora yang berukuran sangat kecil pada banyaknya kotak-kotak pada haemocytometer.

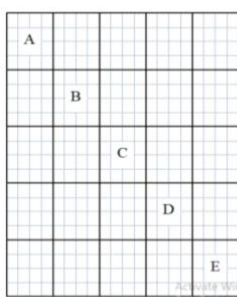

(a)

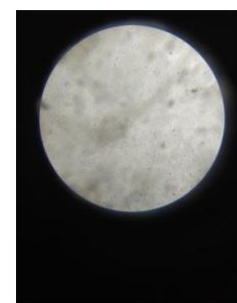

(b)

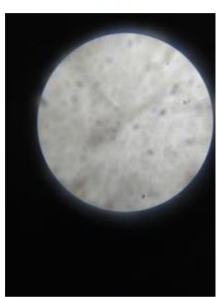

(e)

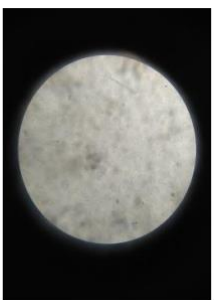

(c)

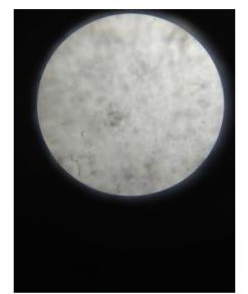

(f)

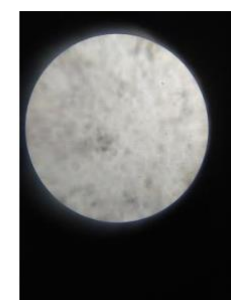

(d)

Gambar 11. Bayangan spora tiap pengenceran pada mikroskop. (a) penampakan kotak pada haemocytometer, (b) penampakan spora larutan induk, (c) penampakan spora pengenceran $10^{-1}$, (d) penampakan spora pengenceran $10^{-2}$, (e) penampakan spora pengenceran $10^{-3}$, (f) penampakan spora pengenceran $10^{-4}$.

\section{KESIMPULAN}

1. Proses perbanyakan Tricodherma sp. dengan media beras diawali dengan explorasi Tricodherma sp., kemudian membuat media PSA untuk perbanyakan Tricodherma sp., setelah itu inokulasi Tricodherma sp. pada media PSA, lalu membuat media beras siap aplikasi, kemudian melakukan inokulasi Tricodherma sp. pada media beras siap aplikasi, langkah terakhir yaitu menghitung kerapatan spora pada media beras siap aplikasi.

2. Kendala perbanyakan Tricodherma sp. dengan media beras meliputi: (1) Media perbanyakan mudah terkontaminasi, solusinya adalah menciptakan kondisi aseptik (steril), baik saat proses pembuatan maupun pasca pembuatan media. (2) Eksplorasi Trichoderma sp. menggunakan media nasi dan media kelapa tidak menghasilkan Trichoderma sp., solusinya adalah mengetahui ciri tanah (rizosfer) yang banyak mengandung Trichoderma sp. Cirinya yaitu tanaman sehat dan tidak terserang penyakit selain itu juga memiliki tanah yang gembur.

\section{UCAPAN TERIMA KASIH}

Penulis menyampaikan penghargaan dan ucapan terimakasih yang sebesar-besarnya kepada: 1 . Ibu Sulistyani Budiningsih, S.P., M.P. Selaku Dekan fakultas Pertanian, Universitas Muhammadiyah Purwokerto atas izin yang diberikan untuk melaksanakan Kerja Praktik, 2. Bapak Teguh Pribadi, S.Hut., M.Si. Selaku Ketua Program Studi Agroteknologi Fakultas Pertanian Universitas Muhammadiyah Purwokerto atas izin dan dukungannya yang diberikan dalam melaksanakan Kerja Praktik, 3. Bapak Teguh Pribadi, S.Hut., M.Si. selaku Pembimbing kerja praktek atas bimbingannya dalam penyusunan laporan kerja praktik ini, 4. Ibu Ardiana Kartika B, S.P. selaku pembimbing dalam kerja praktek di Laboratorium Pengamatan Hama dan Penyakit Tanaman (LPHP) Banyumas.

\section{DAFTAR PUSTAKA}

Barnet HL, Hunter BB. 1998. Illustrated Genera of Imperfect Fungi. Minessota (US): APS Press. 4th edition Bayu.

Chet, I. 1987. Innovative Approaches to Plant Diseases Control. John Wiley and Sons, A Wiley-Interscience Publication. New York.

Harman GE, Howell CR, Viterbo A, Chet I \& Lorito M. 2004. Trichoderma species: Opportuninistic avirulent plant symbionts. Nature Review/microbiology 2:43-56. 
Harman GE. 2000. Changes in perceptions derived from research on Trichoderma harzianum T-22. Plant Disease 84 (4):377-392.

Harman, G.E. 1991. Trichoderma spp., Including T. harzianum, T. viridae, T. koningii, T. hamatun and other spp. Deuteromycetes, Moniliales (Aseksual Classification System) (Ascomycetes, Hypocreales, Usually Hypocrea spp., are Sexual Anamorps, this Life Stage is Lacking or Unknown for Biocontrol Strains). Cornell University. Geneva.

Kalay, A. M. dan A. Talahaturuson. 2014. Perbanyakan Tricodherma harzianum pada Media Berbasis Ela Sagu. Jur. Agroekotek 6 (2): 105-113.

Kalay. A.M. 2005. Penggunaan Trichoderma koningii Oud. sebagai Pengendali Sclerotium rolfsii, Fusarium oxysporium, dan Rhizoctonia solani pada Kacang Tanah. J. Peng Wil 1: 8-13.

Manokaran, R. (2016). Fast Isolation and Regeneration Method for Protoplast Production in Trichoderma harzianum. https://www.researchgate.net.

Mulyati, Yunita W dan Novita T. 2002. Efektivitas penekanan jamur antagonis Trichoderma sp. terhadap penyakit rebah kecambah yang disebabkan oleh jamur Scklerotium rolfsii Sacc. pada tanaman cabai.

Novizan. 2002. Membuat dan Memanfaatkan Pestisida Ramah Lingkungan. Jakarta: Agromedia Pustaka.

Oka IN. 1995. Pengendalian Hama Terpadu dan Implementasinya di Indonesia. Yogyakarta: Gadjah Mada University Press.

Pusat Penelitian dan Pengembangan Perkebunan. 2014. Pengendalian Penyakit Jamur Akar Putih (JAP) pada Pembibitan Karet dengan Trichoderma sp. http://Perkebunan.litbang.pertanian.go.id.

Schuster, A., dan Schmoll, M. 2010. Biology and biotechnology of Trichoderma. Appl Microbiol Biotechnol, 87(3): 787-799.

Semangun H. 1996. Ilmu Penyakit Tumbuhan. Yogyakarta: Gadjah Mada University Press.

Shofiyani dan Suyadi. (2014). Kajian Efektifitas Penggunaan Agensia Hayati Trichoderma sp Untuk Mengendalikan Penyakit Layu Fussarium Pada Tanaman Bawang Merah Diluar Musim. Prosiding Seminar Hasil Penelitian LPPM UMP 2014.

Subagio, A. Potensi Daging Buah Kelapa sebagai Bahan Baku Pangan Bernilai. Jurnal Pangan 20 (1).

Susanti, W. I. 2015. Kajian Sifat Kimia dan Biologi Tanah Rizosfer Bambu sebagai Disease Suppresive Soil. Tesis. Bogor (ID): Sekolah Pascasarjana IPB.

Syahnen. D.D.N. Sirait dan S.E. Pinen. 2014. Teknik Uji Mutu Agens Pengendali Hayati (ABK) di Laboratorium. Medan: Balai Besar Perbenihan dan Proteksi Tanaman Perkebunan (BBPPTP).

Syahputra, M. H., Azwir A., dan Irdawati. Isolasi Trichoderma Spp. Dari Beberapa Rizosfer Tanaman Padi Asal Solok. Journal Biosains 1(2): 97-105.

Taufik M. 2008. Efektivitas agen antagonis Trichoderma sp. pada berbagai media tumbuh terhadap penyakit layu tanaman tomat. Prosiding. Seminar Ilmiah dan Pertemuan Tahunan PEI PFI XIX Komisariat Sulawesi Selatan. Makassar. 240-249.

Tehrani, A.S., and S. Nazari. 2004. Antagonistic Effects of Trichoderma harzianum on Phytophthora drechsleri, the Casual Agent of Cucumber Damping-off. International Society for Horticultural Science (ishs) Acta Horticulturae 635: xxvi International Horticultural Congress: Managing SoilBorne Pathogens: a Sound Rhizosphere to Improve Productivity in Intensive Horticultural Systems. 